\title{
Akhlak Tasawuf Basis Pendidikan Multikultural Di Indonesia
}

\author{
Hadarah $^{1}$ \\ ${ }^{1}$ IAIN Syaikh Abdurrahman Siddik Bangka Belitung
}

\begin{tabular}{|c|c|}
\hline Info Artikel : & ABSTRAK \\
\hline Diterima 12 April 2020 & Penelitian ini bertujuan untuk mendeskripsikan bagaimana sikap aklah yang \\
\hline Direvisi 20 April 2020 & diajarkam ilmu tasawuf dapat menjadi landasan Pendidikan multicultural. \\
\hline Dipublikasikan 27 April 2020 & $\begin{array}{l}\text { Metode yang digunakan adalah dengan metode penelitian kualitatif } \\
\text { fenomenologis, dengan melalui pendekatan wawancara mendalam dan } \\
\text { pengamatan langsung di lapangan, serta observasi. Adapaun hasil dari } \\
\text { penelitian ini adalah desain Pendidikan Multikultural yang berbasis Akhlak }\end{array}$ \\
\hline Kata Kunci: & Tasawuf. Kolaborasi antara konsep pendidikan multikultural di satu sisi dan \\
\hline Akhlak Tasawuf & perilaku sufi pada ajaran tasawuf dilain sisi. Pada dasarnya kedua unsur \\
\hline Basis Pendidikan & tersebut sudah berjalan dengan waktu yang cukup panjang dan telah \\
\hline Multikultural & $\begin{array}{l}\text { kedua unsur dalam sistim pendidikan multikulturak berdimensi sufi yang } \\
\text { dimungkinkan menjadi suatu pola baru yang lebih teduh dan menciptakan } \\
\text { kedamaian untuk bangsa Indonesia }\end{array}$ \\
\hline
\end{tabular}

\section{Keywords:}

Sufism's Morals

Education Base

Multicultural

\section{ABSTRACT}

This study aims to describe how the attitude that is taught by Sufism can be the basis of multicultural education. The method used is phenomenological qualitative research methods, through in-depth interviews and direct observation in the field, as well as observation. The results of this study are the design of Multicultural Education based on Moral Tasawuf. Collaboration between the concept of multicultural education on the one hand and Sufi behavior on Sufism on the other hand. Basically these two elements have been running for quite a long time and have been implicated in various aspects, but this section offers collaboration between the two elements in a multicultural education system with a Sufi dimension which is possible to become a new pattern that is more shady and creates peace for the Indonesian people

(c) (i) This is an open access article distributed under the Creative Commons Attribution License, which permits unrestricted use, distribution, and reproduction in any medium, provided the original work is properly cited. (O2019 by author.

\section{Koresponden:}

Hadarah

Email: hadarahrajab22@gmail.com

\section{Pendahuluan}

Indonesia Negara yang berpendudukan mayoritas Mulsim yang berlandaskan asa pancasila menjadikan negeri ini tempat belajar bagi bangsa lain khususnya konsep Islam Multikultural (Anam, 2016). Era globalisasi saat ini, melingkupi kehidupan masyarakat secara global dan penuh intrik-intrik arus globalisasi (Suasana,2019). yang bukan hanya bermuatan positif, namun juga mengandung bahaya perpecahan sebagaimana prediksi banyak pihak tentang kemungkinan terjadinya benturan antar peradaban satu dengan peradaban yang lain (Suasana,2019). Benturan yang ditengarai oleh beberapa faktor; yakni politik, budaya, sosial, ekonomi, ras, demikian juga agama(Suryana,2019).

Watak kebangsaan nasionalisme bisa dilihat dari watak dan sikap muhammadiyah terhadap pancasila sebagai dasar Negara Rupublik Indoensia. Sebagaiana pendapat Munir Mulkhan dengan tegas mengatakan bahwa muhammadiyah memiliki konsistensi yang sangat tinggi dalam penerimaan dan pengakuan kepada pancasila. Sikap dan pandangan para tokoh Muhammadiyah sepanjang sejarah kemerdekaan Indoensia yang terlibat secara langsung dalam perumusan pancasila dan UUD 1945 diantaranya adalah Ki. BAgus Hadikusumo, Ir Soekarno, Mr. Kasman Singadimedja termasuk pula Kahar Muzakkir (Suasana,2019). 
Sebuah Negara yang demikian besar, dengan masyarakat yang multi etnis, suku, agama dan budaya menjadi sebuah fenomena menarik. Itulah mengapa Negara ini menjadi berbeda jauh dari peradaban bangsa lain yang justru sebagai Negara Islam namun penuh dengan gejolak (Mulyono, 2017). Sebah Negara selayaknya selalu mempunyai ideology dan palsafah kenegaraan, apapun namanya, kebetulan di Indoensia Pancasila sebagai palsafat Negara bukan tidak mungkin mendapatkan keritikan peds dari kelompok masyarakat tertentu yang cenderung menolaknya, akan tetap pemerintahan kokoh dengan pendiriannya sehingga Pancasilah masih eksis sekalipu dihadapkan dengan anti Pancasilais (Republika,2007) dapat disaksikan mucnulnya gerakan dari kelompok Islam pada momentum pemeilihan Presiden RI era Jokowi yang berpasangan dengan KH. Ma'ruf Amin.

Pihak lembaga pendidikan di Indonesia mulai tingakt sekolah dasar hingga PErgruan Tinggi sangat penting membuat rumusan baru terhadap pendidikan karakter bangsa yang tidak hanya pada pendidikan moral yang standar, namun perlu polsarisasi standar pembinaan akhlak pada dimensi yang lebih mendalam yakni pendidkan Akhlak Tasawuf(Anam, 2016). Pemerintah melalui lembaga pendidikan sudah harus sensitive terhadap arus perubahan globalisasi ini.

Pernyataan kepada BPIP yang baru dilantik oleh Presiden Joko Widodo Prof. Dr. Yudian Wahtudi tentang aagama dan Pancasila yang kemudian mendadak menjadi buah bibir dengan pernyataan bahwa Agama adalah musuh Pancasila (Rofiq, 2020). Dengan berdirinya unit lembaga tentang pertahanan Pancasila yang dikenal dengan nama BPIP Pergerakan demokrasi menuntut pengakuan perbedaan dalam tubuh bangsa Indonesia yang memiliki berbagai ragam suku dan agama (sutoyo, 2015). Merancang model pendidikan baru sebagai alternatif menjaga menghimpunan beragam budaya masyarakat bangsa ke era globalisasi, memupuk nilai secara fundamental, mulai dari tingkat siswa yang beragam suku, ras, dan agama, mengembangkan perilaku saling menghargai dan memahami satu sama lain. Dalam hal ini pendidikan multikultural berlandaskan nilai-nilai ajaran Sufi adalah sebuah alternatif dan akomodatif atas berbagai problematika masyarakat yang heterogen itu (Futaqi, 2018).

Dari latarbelakang masalah di atas, maka yang menjadi pokok permsalahan adalah bagaimana model Akhlak Taawuf menjadi basis pendidikan multikultural di Indoensia dan bagaimana implementasinya dalam kurikulum pembelajaran secara berjenjang baik penddikan dasar, menengah hingga tingkat Perguruan Tinggi yang sejalan dengan harapan pemerintah pada setiap lembaga pendidikan, hal ini sedapat mungkin menjadi perhatian semua elemen masyrakat. Dan permasalahan secara universal adalah Pergerakan demokrasi menuntut pengakuan perbedaan dalam tubuh bangsa Indonesia yang memiliki berbagai ragam suku, etnis, kepercayaan dan agama.

\section{Metode}

Penulisan Artikel merupakan hasil penelitian dengan metode penelitian kualitatif fenomenologis, dengan melalui pendekatan wawancara mendalam dan pengamatan langsung di lapangan, serta observasi (Kuswarno, 2006). maka diketahui bahwa terdapat kecenderungan sikap dan perilaku masyarakat muslim Melayu Bangka dapat membangun masyarakat multicultural, melaksanakan penelitian komunikasi dengan menggunakan metode kualitatif merupakan pengalaman unik dan menarik dan dinilai banyak pihak bahwa metode penelitian kualitiatif sangat sesuai digunakan untuk menggunakan realitas sosial yang sesungguhnya, khusus dalam bidang perilaku manusia, sebagaimana ungkapan Watt dan Berg (subadi,2006). Di Indonesia pada umumnya secara fenomena masyarakat yang beragama Islam lebih banyak dibandingkan dengan penganut agama lainnya, namun seiring perkembangan roda pemerintahan masyarakat sudah mulai mengalamai perpecahan akibat adanya keingininan kelomppok Agama Islam untuk membentuk kelompok yang "anti" pancasila bahkan seolah-olah anti pemerintahan. Pemerintah dengan tanggap membaca fenomena lalu kemudian membuat berbagai planning antisipatif salah satunya adalah BPIP yang berada pada lembaga khusus yang menuai banyak kontropersi(subadi,2006).

Adapun yang menjadi lokasi penelitian adalah provinsi kepulauan Bangkabelitung yang terdiri dari satu kotamadya yaitu Kota Pangkal Pinang. Adapun tujuan penulisan artikel ini adalah merancang model pendidikan baru sebagai alternative, menjaga, menghimpun beragam budaya masyarakat bangsa ke era globalisasi, memupuk nilai secara fundamental, mulai dari tingkat siswa hingga mahasiswa, mengembangkan perilaku saling menghargai dan memahami satu sama lain. Dalam hal ini pendidikan multikultural berlandaskan nilai-nilai ajaran Sufi sebuah alternatif yang akomodatif atas berbagai problematika masyarakat yang heterogen. 


\section{Hasil dan Pembahasan}

\section{A. Pengertian Akhlak Tasawuf}

Akhlak tasawuf sebagai basis Pendidikan multikultural (Prabencana, 2016), sebagaimana pengertian akhlak berasal dari bahasa Arab yaitu "akhlakun" sebagai bentuk jamak dari kata "khuluqun"yang berarti budi pekerti, perangai atau kelakuan, tabiat(Mizwar, 2015). Mengenai masalah multicultural merupakan suatu tantangan yang mengedepankan majemuknya nilai-nilai (Nugroho, 2016). mekanisme dan struktur sosial dalam bingkai human being (zainiati, 2007). Dalam kesadaran pluralisme manusia dihadapkan pada proses pembelajaran yang terus menerus bergulir sepanjang hidupnya terhadap sesuatu di luar pribadi dan identitas monocultural (Sutoyo,2015). Dalam kedua konteks tersebut yakni manusia dan multikulturak, banyak perbenturan yang biasa terjadi. Tetapi itu adalah impact yang tidak bisa dihindari karena yang mau dicairkan adalah manusia sebagai realitas-realitas human being manusia sebagai yang berakal budi (Annur, 2014).

Pentingnya pendidikan Akhlak sebagai dasar pendidikan multicultural (Suciartini, 2017) menjadi lebih urgen ketika dilihat dari realitas kondisi masyarakat Indonesia yang terdiri dari berbagai perbedaan suku, agama, bahasa dan budaya. Jumlah penduduk hampir mencapai kurang lebih 210 juta jiwa, terdiri dari 13.000 pulau besar dan kecil, 300 suku yang menggunakan bahasa hampir mencapai 210 jenis bahasa, dengan beberapa agama, belum lagi dengan aliran kepercayaan dan sekte-sektenya. Mulai dari yang dianggap sah menurut kesepakatan ulama hingga yang disesatkan oleh kelompok tertentu (yang masih dalam pro dan kontra) (Arifin, 2012).

\section{B. Pola Baru Pendidikan Multikultural}

Menurut Bunnet pendidikan multicultural memiliki tiga macam program (Mania, 2010). yang dapat diterapkan oleh sekolah dan masyarakat secara keseluruhan yaitu:

Pertama, program yang berorientasi pada materi (content-oriented program) yang merupakan pendidikan multicultural yang paling umum dan dengan mudah dapat dipahami, tujuannya adalah memasukkan materi tentang kelompok budaya yang berbeda dalam kurikulum dan materi pendidikan dalam rangka meningkatkan pengetahuan siswa mengenai kelompok-kelompok tersebut. Sederhananya adalah menambahkan pada bagian kurikulum standar muatan multicultural (Faziah, 2008). Atau pada level yang lebih di atasnya adalah merubah kurikulum secara aktif dengan tiga tujuan; yaitu 1) mengebangkan muatan multicultural melalui berbagai disiplin. 2) memasukkan pembobotan sudut pandang dan pespektif yang berbeda dalam kurikulum, 3) mengubah aturan yang pada akirnya mengembangkan paradigm baru bagi kurikulum (Wijaya, 2016)

Kedua, program yang berorientasi siswa (student-oriented program), yang dimaksudkan untuk meningkatkan prestasi akademik kelompok siswa yang berbeda, meskipun ketika itu mereka tidak memberikan perubahan besar dalam muatan kurikulum. Beberapa program ini tidak dirancang untuk mengubah kurikulum atau konteks sosial pendidikan, melainkan membantu siswa bahasa dan budaya yang berbeda untuk sama menciptakan perubahan dalam mainstream pendidikan, terdapat beberapa kategori program yang khas seperti; 1 ) program yang menggunakan riset dalam medel belajar yang berbasis budaya (culturally-base learning styles) dalam menentukan gaya mengajar mana yang digunakan pada kelompok siswa tertentu (McIntyre, 1996), 2) program dua bahasa (bilingual) atau dua budaya (bi-cultural)(Arafah, 1945), 3). Program bahasa yang mengandalkan bahasa dan budaya sekelompok siswa minoritas.

Ketiga, program yang berorientasi sosial (social-oriented program) yang berupaya mereformasi pendidikan maupun konteks politik dan budaya pendidikan yang bertujuan bukan untuk meningkatkan prestasi akademik atau menambah sekumpulan pengetahuan multicultural, melainkan memiliki pengaruh yang sangat signifikan dalam menigkatkan toleransi budaya dan ras serta mengurangi bias. Di samping itu, kategori program ini tidak hanya meliputi program yang dirancang untuk menstrukturkan kembali dan menyatukan sekolah, tetapi juga program ini dirancang untuk meningkatkan semua bentuk hubungan di kalangan kelompok etnik dan ras dalam program belajar bersama tanpa membedakan perbedaan-perbedaan yang ada pada setiap individu (Hanum, 2013). Bentuk pendidikan multicultural ini menekankan "hubungan manusia' dalam semua bentuknya, dan menggabungkan beberapa karakteristik dua bentuk program lainnya ( Somatri, 2016) yaitu program yang menuntut perbaikan kurikulum dalam rangka menekankan kontribusi sosial yang positif dari kelompok etnis dan budaya, sambil menggunakan riset tentang model belajar untuk meningkatkan prestasi siswa dan mengurangi ketegangan dalam ruang kelas (Nurdyansyah, 2016). 
Untuk mengimplementasikan pendidikan multicultural di Indonesia memang bukan sesuatu yang taken for granted atau trial and eror, tetapi butuh kerja keras dan perjuangan yang Panjang (Adhani, 2014). Hal ini dikarenakan Indoensia baru memulai pendidikan multicultural ini, oleh karenanya diperlukan suatu rujukan di negaranya. Jadi yang harus dilakukan dalam implementasi pendidikan multicultural di Indonesia adalah mulai proses persiapan rancangan kurikulum berbasis kompetensi siswa pada mata pelajaran yang relevan, sebab multiculturalisme barulah sebuah gerakan dan belum menjadi sebuah ilmu yang komprehentif apalagi sikap dan perilaku. Desain kurikulum 2013 oleh Kementrian Pendidikan Nasionalmemang telah terkaper berbagai konsep di dalamnya, namun mengalami distorsi dibebrabgai elemen, elemen utama adalah respon para guru, apakah guru dapat mengimplementasikannya dengan sungguh-sungguh dan merata, faktanya juga belum memadai oleh karena banyak factor penghabatnya, mulai dari saran pendidikan, kebijakan pimpinan dan komitmen serta kekompakan guru, serta kesejahteraan guru juga tidak kalah pentingnya dalam meningkatkan mutu dan kualalitas siswa secara umum, dan bagaimana penerapan kurikulum berbasis perilaku siswa yang memiliki tenggang rasa antara satu dengan yang lain ?.

\section{Pengaruh Perilaku Sufi Terhadap Pendidikan Multikultural}

Islam mengajarkan agar semua ummat manusia yang beragama Islam menjalankan agama secara kaffah tidak terpenggel-penggal atau varsial. Unsur-unsur agama berupa Islam, Iman dan Ihsan senantiasa terpadu dalam satu kesatuan komponen nilai secara absolut, sebagaimana ajaran Syariah dalam rukunrukun Islam dan ajaran Tauhid dalam konsep keyaninan pada semua kegaiban yakni; Iman kepada Allah, Iman kepada Kitab, Iman keada Malaikat, Iman kepada Rasul, Iman kepada Qada' dan Qadar serta Iman kepada hari akhirat sebagai hari kemanngkitan untuk menerima ganjaran atas semua amal perbuatannya di dunia.

Ajaran dasar Islam salah satunya adalah bahwa manusia tersusun dari dua unsur, unsur roh dan jasad. Sedangkan roh itu berasal dari hadirat Tuhan, wa nafakkhu fihi ruhi, dimana roh ini akan kembali kepada Tuhan (Futaqi, 2018). Tuhan adalah suci dan roh yang datang dari Tuhan juga suci dan akan kembali kepada Tuhan jika dalam keadaan suci (Ismail, 2013), sedangkan jika ia menjadi kotor sebab masuk ke dalam manusia yang bersifat materi, maka ia tidak akan kembali ke tempat asalnya. Oleh karena itu harus diusahakan supaya roh suci dan manusia menjadi baik (Rahmat, 2016). Dalam Islam diajarkan antran-aturan manusia yang baik, yakni tersimpul dalam syariat yang mengambil bentuk salat, puasa, zakat, haji, dan ajaran-ajaran mengenai moral atau dalam dunia sufi disebut akhlak Islam (Siroj, 2006). Dalam hadis nabi bersabda "Ia datang untuk menyempurnakan budi pekerti luhur (Lubis 2012), innama bu'istu liutammima makarim al-akhlaq (Siroj, 2006)

Manusia sebagaimana unsur penciptaannya yang terdiri dari jasmani dan rohani. Jasad diri manusia selanjutnya disebut unsur materi, yaitu tubuh yang senantiasa mempunyai kepentingankepentingan sedangkan unsur roh disebut immateri yaitu jiwa yang mempunyai dua daya; daya fikir yang disebut akal dan merasa disebut zauq atau zihn (Pramono,2005).

Dalam konsep Tao hakikatnya tak dapat diuraikan, namun mnafestasi dan fungsinya dapat diidentifikasikan dengan segala sesuatu di alam ini. Inilah yang disebut Sachiko Murata sebagai "dualitas Ilahi"( Maftuchah, 2014), memiliki kesamaan dengan Brahman dalam Hindu, Logos dalam Kitab Suci Kristen fundamental fisik (Pramono,2005). Dalam bahasa Danah Zohar dan Lan Marshall, Tao atau Tuhan dalam tradisi sematik, sebagai analog dengan hampa kuantum, merupakan transendensi capaian tertinggi fisika (Zohar,2007). Ini menekankan pada sebuah keyakinan akan relevansi ilmiah ajaran Tao. Tao adalah gabungan Yin dan Yang, yakni alur keselaran bergantungan (Too, 1996), Yang kemudian menghasilkan harmoni atau keselerasan. Harmoni ini merupakan penyatuan subjek dan objek menempati kedudukan penting dalam kreativitas seni.

Kesempurnaan ciptaan manusia adalah karena ia memiliki daya dan kemampuan yang lebih dari ciptaan lainnya, yakni manusia memiliki dua daya; daya berfikir yang disebut akal dan daya merasa disebut sebagai zauq atau zihn(Rahmat, 2016). Dalam ajaran Islam kedua daya tersebut telah dikembangkan oleh ulama-ulama muslim. Kaum filosof dan teolog lebih mengembangkan daya berpikir (akal), maka dara rasa (zauq)(Dewi,2015) lebih dikembangkan oleh kaum sufi. Kelompok sufi adalah golongan umat Islam yang belum merasa puas dengan pendekatan diri kepada Tuhan melalui ibadah pada umumnya seperti; salat, puasa, zakat, dan haji. Mereka menganggap ibadah umum tersebut belum memenuhi kebutuhan spiritual mereka (Siroj, 2016). Oleh karena itulah mereka mencari jalan menuju Tuhan lebih dekat hingga mereka merasa dapat berjumpa dengan Tuhan melalui hati sanubari (bashariah) di jalan tasawuf atau yang oleh orang Barat disebut mistisisme Islam. 


\section{Pendidikan Multikultural Dalam Konsep Akhlak Tasawuf}

\section{A. Pendidikan dalam ilmu tasawuf}

Tasawuf adalah menjadi pijakan para para pencari Tuhan demikian kaum sufi (Fathrudi, 2017). yang diolah dalam praktek tarekat dengan rutin menjalankan rangkaian ritual untuk munajab pada Tuhan (Rahman, 2011) senantiasa mengolah mata batin, menjalin hubungan secara vertikal (hablun minallah) dan hubungan terhadap sesama manusia (hablun minannas). Senantiasa melakukan pensucian batin (riyadahtun nafs). Kata tasawuf berasal dari kata tashawwafa yang berarti memakai pakaian dari bulu domba (al-shuf). Oleh karena itu, orang yang hidupnya semata-mata dalam ke-sufi-an yang biasanya berpakaian dari bulu domba disebut dengan shufi. Adapun bentuk lain dari istilah sufi adalah shufiyyah yang muncul pada tahun 199 H/814 M menunjukkan kepada suatu aliran dari beberapa aliannya (Abdurahman, 2018)

\section{B. Pandangan Tasawuf}

Pendapat para tokoh sufi tentang defenisi tasawuf (Ardiyani, 2018) menurut Ibrahim Basyumi telah memilih empat puluh definisi tasawuf yang diambil dari pendapat para tokoh-tokoh sufi yang hidup pada abad ke tiga Hijriah antara tahun 200-334 H. defenisi, yaitu 1). Tasawuf dalam tataran elementry (al-Bidayah), 2) tasawuf dalam tataran intermediate (al-Mujahadah), 3) tasawuf dalam tataran advance (al-Mazaqah).

Defenisi al-Bidayah menurut Abu al-Husain al-Nuri (w.295 H). menyatakan bahwa kaum sufi adalah kaum yang bersih dari segala kekeruhan dan penyakit batin manusia, dan mereka bebas dari pengaruh syahwat, hingga mereka itulah orang-orang yang terpilih di barisan utama dan derajat yang tinggi dalam kebenaran.

Pada tataran al-Mujahadah, tasawuf berkisar pada penghiasan diri dengan suatu perbuatan yang diingini oleh agama (al-khair) dan kebiasaan yang baik (al-ma'ruf) (Belk. 2011). Dalam hal ini ada terdapat beberapa pendapat sebagai berikut: 1). Abu Muhammad al-Jariri mengartikan tasawuf adalah masuk ke dalam akhlak yang mulia dan keluar dari semua akhlak yang lain. 2). Al-Katany menyatakan bahwa tasawuf itu adalah akhlak yang mulia, barangsiapa yang bertambah baik akhlaknya, bertambah pula kejernihan hatinya (Hadarah, 2019) 3). Al-Nury menjelaskan bahwa yang disebut tasawuf itu bukan sekedar tulisan dan ilmu, melainkan ia adalah akhlak yang mulia. Sekiranya ia hanya sekedar tulisan maka dapat diusahakan dengan bersungguh-sungguh, seandainya ia ilmu, tentu dapat dicapai dengan belajar. Akan tetapi, tasawuf adalah berakhlak dengan akhlak Allah. Keadaan ini tidak bisa diperoleh dengan tulisan dan ilmu.

Selanjutnya, pada tataran al-Mazaqah menguraikan tentang kehidupan manusia dalam tataran tasawuf segala kemauan ditundukkan untuk melarutkan ke dalam kehendak Tuhan (Fahrudi, 2011), dengan jalan rindu (isyq) dan intuisi (wajd). Sedangkan kegiatan hati dan usia dikerahkan sepenuhnya kepada Allah sehingga hubungan antara diri manusia dengan Tuhannya lebih kuat dan intim, bersih, dan menyatu. Perasaan yang dialami oleh sufi digambarkan Abud Husain al-Muzyu dalam tasawuf sebagai penyerahan diri secara bulat kepada al-Haq (Stafa, 2001) Membiarkan diri dengan Allah menurut kehendaknya. A1Syibly mengibaratkan sufi dalam ilmu tasawuf bagaikan anak-anak kecil di pangkuan Tuhan. Sebagaimana Al-Junaid memandang bahwa tasawuf dalam diri sufi bagaikan penyeraan diri manusia dengan Tuhannya yang demikian intim tanpa penghubung, sama pandangannya al-Hallaj menyatakan bahwa tasawuf itu kesatuan zat. Nilai yang paling utama adalah pada tatanan manusia yaitu pada perilaku sufi, (Fahrudi, 2011) yang kemudian menjadi cerminan akhlak mulia.

\section{Desain Pendidikan Multikultural Berbasis Akhlak Tasawuf}

Pendidikan Multikultural yang berbasis Akhlak Tasawuf merupakan penawaran model baru dalam dunia pendidikan dengan harapan adanya kerjasama dan dukungan dari semua pihak, baik pemerintah maupun masyarakat terutama para ulama Muslim. Kolaborasi antara konsep pendidikan multicultural di satu sisi dan perilaku sufi pada ajaran tasawuf dilain sisi. Pada dasarnya kedua unsur tersebut sudah berjalan dengan waktu yang cukup panjang dan telah merimplikasi ke berbagai aspek (Hadarah, 2019), namun pada bagian ini menawarkan kolaborasi kedua unsur dalam sistim pendidikan multikulturak berdimensi sufi (Rohayati, 2011) yang dimungkinkan menjadi suatu pola baru yang lebih teduh dan menciptakan kedamaian untuk bangsa Indonesia.

Dalam ilmu tasawuf, para sufi menjalankan Konsep pendidikan Islam dalam dimensi sufistiknya dikelolah berdasarkan tiga unsur dasar sebagi jihad akbar melalui tiga rangkaian proses; pertama Takholli, kedua; Taukhalli, ketiga; Tajalli. Dikembangkan pada pencapaian tertinggi yaitu insan kamil yang disebut sebagai manusia sempurnah sebagai model manusia yang dikehendaki oleh Islam (Ardiyani, 2018) Pendekatan yang digunakan adalah kualitatif dengan bersifat sociology. Meskipun disadari bahwa terdapat perbedaan pola yang sangat nyata terutama pada prakter-prakter keilmuan dan respon masyarakat secara 
terpisahkan. Pencapaian pengetahuan tertinggi adalah ma'rifat kepada Allah sebagai Pencipta dan menjadi tujuan paling akhir (Abdurrahman, 2018).

\section{Kesimpulan}

Penawaran model pendidikan multikultural berbasis Akhlak Tasawuf terkesan baru, namun sesungguhnya bukan baru secara substansi. Yang ditawarkan dalam tulisan ini adalah model atau rancangan penggabungan dua unsur penting yang selama ini sudah tumbuh berkembang subur di Negara Indonesia, akan tetapi kemasannya memang belum permanen (louncing), masih perlu sosialisasi. Dan menariknya hal ini juga sudah merupakan pengejawantahan atas pesan pendiri bangsa yang termaktub di dalam sila "persatuan Indoensia" pada Pancasila, berada di antara sila-sila, "Kemanusiaan yang adil dan Beradab". Dan "Kerakyatan yang Dipimpin oleh hikmat kebijaksanaan dalam permusyawaratan Perwakilan".

Hal ini mengandaikan persatuan nasional yang pelbagai lintas: agama, etnis, ras, dan kelompok sosial serta aliran kepercayaan, hanya bisa tergabung kukuh jika dirawat oleh spirit dan visum tentang "kemanusiaan" yang bertumpuh tidak hanya keniscayaan penghormatan hak-hak dasar manusia (human right) tetapi juga bahkan ini yang terpenting, menjunjung martabat manusia (human dignity). Martabat manusia hanya bisa terawat bila dibangun di atas keadilan dan keadaban.

Persatuan nasional yang bhineka, juga hanya bisa dipertahankan di atas tatakelola pemerintahan demokrasi, berbasis hikmah dan kearifan serta keadaban local, dimana "daurah rakyat" mengatasi seluruh bentuk kedaulatan kekuasaan yang ada. Patut direnungkan warning sila kelima, "Keadilan sosial bagi seluruh rakyat Indonesia". Akan berbunyi keras, jika rasa keadilan sosial, baik sosio-politik maupun sosioekonom, tak tersentuh sungguh-sungguh oleh para penyelenggara Negara. Semua menunjukkan perilaku positif dan mencerminkan nilai-nilai tasawut Islam. Dan akhinya, para pendiri bangsa juga mengingatkan dalam sebilah perspektif, bahwa bangsa ini percaya dan yakin atas kekuatan-kekuatan transcendental dan adikodrati dan dinarasikan pada sila "Ketuhanan yang Maha Esa". Hal tersebut mengandaikan bahwa problem solver untuk sejumlah permasalahan akut bangsa ini, jangan hanya bertumpuh pada analisis rasional-intelek, sosio-empirik, tetapi juga dengan ketajaman nurani dan intuisi batin serta pengharapan tak putus-putusnya kepada kerahmatan Tuhan Yang Maha Esa, satu persatu persoalan bangsa ini bisa terurai dalam satu "kode kebangsaan" tunggal: Indonesia Raya.

Ma'rifat tiada lain adalah tingkat pengenalan parifurnah, mengenal diri sendiri sebagai insan mansuia, maka dengan demikian dapat mengenali hakekat kebenaran. Semuanya dapat dicapai melalui olahan jiwa dan aktifitas raga secara bersinergi dengan baik yang berlandaskan pada kekuatan "Rasa" yang pada akhirnya mewujudkan tindakan menerimah segala perbedaan yakni toleran kepada sesama ciptaan Tuhan. Kurikulum pendidikan multikultural masih perlu penajaman warna pada unsur sufi dan pembinaan secara berkesinambungan dari semua pihak tanpa ada sektarianisme. Pendidikan akhlak secara sufistik sebuah keniscayaan dan onovasi, tidak ada salahnya jika selalu mencoba membuat konsep dan rancangan baru sehingga pola pendidikan tidak monoton atau kaku.

\section{Referensi}

A. Dirgantoro, 'Dirgantoro, A. (2016). Implementation Of Multicultural Education Ineducationalperspective For Cross Cultural Psychologystudy In Indonesia. Proceedings International Seminar FoE (Faculty of Education), 96-108.', Proceedings International Seminar FoE (Faculty of Education), 2016.

A. Fahrudi, 'Fahrudi, A. H. (2017). Al-Insan Al-Kamil Dalam Tasawuf Ibn 'Arabi. MIYAH: Jurnal Studi Islam, 11(1), 11-34.', Miyah: Jurnal Studi Islam, vol. 11, no. 1, 2017, pp. 11-34.

A. Rahmat, 'Rahmat, A. (2016). Konsep Manusia Perspektif Filosof Muslim. Jurnal Kariman, 4(2), 41-62.', Jurnal Kariman, vol. 4, no. 2, 2016, pp. 41-62.

Adhani, Yuli, 'Konsep Pendidikan Multikultural Sebagai Sarana Alternatif Pencegahan Konflik', SosioDidaktika: Social Science Education Journal, vol. 1, no. 1, 2014, pp. 111-21.

Anam, Ahmad Muzakkil, Penanaman nilai-nilai pendidikan multikultural di perguruan tinggi: Studi kasus di Universitas Islam Malang, Universitas Islam Negeri Maulana Malik Ibrahim, 2016.

Annur, Barsihannor, 'Sayyed Hossein Nasr (Sufisme Masyarakat Modern)', Jurnal al-Hikmah, vol. 15, no. 2, 2014, pp. 127-34.

Arafah, Burhanuddin, 'The Development And Challenges Of Indonesian Language As An Academic Language', Constitution, vol. 18, no. 1945, 1945.

Al Arifin, Akhmad Hidayatullah, 'Implementasi Pendidikan Multikulutral dalam Praksis Pendidikan di 
Indonesia', Jurnal Pembangunan Pendidikan: Fondasi dan Aplikasi, vol. 1, no. 1, 2012.

Beck, Herman L., 'The Contested State of Sufism in Islamic Modernism: The Case of the Muhammadiyah Movement in Twentieth-Century Indonesia', Journal of Sufi Studies, vol. 3, no. 2, Brill, 2014, pp. 183219.

D. Abdurahman, 'Abdurahman, D. (2018). Islam, Sufism, and Character Education in Indonesia History. Tawarikh, 9(2), 159-176.', Tawarikh, vol. 9, no. 2, 2018, pp. 159-76.

D. Ardiyani, 'Ardiyani, D. (2018). Maqam-Maqom Dalam Tasawuf, Relevansinya Dengan Keilmuan Dan Etos Kerja. Suhuf, 30(2), 168-177.', Suhuf, vol. 30, no. 2, 2018, pp. 168-77.

D. Kurikulum, P. Isu, Kurikulum, D., \& Isu, P. D. A. N. (N.D.). A. Prinsip Pengembangan Desain Kurikulum.

Dewi, Ernita, 'Konsep Manusia Ideal dalam Persepektif Suhrawardi Al-Maqtul', Substantia, vol. 17, no. 1, 2015, pp. 41-54.

Fahrudi, Ah Haris, 'Al-Insan Al-Kamil Dalam Tasawuf Ibn 'Arabi', Miyah: Jurnal Studi Islam, vol. 11, no. 1, 2017, pp. 11-34.

Fauziah, Nur, Pendidikan Agama Islam berwawasan multikultural: Telaah terhadap pembelajaran pendidikan agama Islam di sekolah, Universitas Islam Negeri Maulana Malik Ibrahim, 2008.

Futaqi, Sauqi, 'Nalar Sufistik Islam Nusantara Dalam Membangun Perdamaian', DAR EL-ILMI: Jurnal Studi Keagamaan, Pendidikan dan Humaniora, vol. 5, no. 2, 2018, pp. 1-15.

H. Zainiyati, '[1] H. S. Zainiyati, "Pendidikan Multikultural: upaya membangun keberagamaan inklusif di sekolah,” Islam. J. Stud. Keislam., vol. 1, no. 02, pp. 135-145, 2007.', ISLAMICA. Jurnal Studi Keislaman, vol. 1, no. 02, 2007, pp. 135-45.

Hadarah, Hadarah and A. Gani, 'The Implementation of Tarekat Naqsyabandiyah's Sufism Values in South Celebes', Journal of Social Studies Education Research, vol. 10, no. 2, 2019, pp. 243-69.

Hanum, Farida and M. Si, 'Pendidikan Multikultural dalam Pluralisme Bangsa', Universitas Negeri Yogyakarta, 2013.

Indonesia, Republik, 'Undang-undang Republik Indonesia nomor 20 tahun 2003 tentang sistem pendidikan nasional', Jakarta: Pemerintah Republik Indonesia, 2003.

Iqbal, Muhammad and M. Ag, Pemikiran Politik Islam, Kencana, 2015.

Ismail, Syarifah, 'Tinjauan Filosofis Pengembangan Fitrah Manusia dalam Pendidikan Islam', $A t-T a$ 'dib, vol. 8, no. 2, 2013.

Kurikulum, Desain and Prinsip D.A.N. Isu, A. Prinsip Pengembangan Desain Kurikulum.

Kuswarno, Engkus, 'Tradisi fenomenologi pada penelitian komunikasi kualitatif: sebuah pengalaman akademis', MediaTor (Jurnal Komunikasi), vol. 7, no. 1, 2006, pp. 47-58.

Lubis, Agus Salim, 'Konsep Akhlak dalam Pemikiran al-Ghazali', Jurnal Hikmah, vol. 6, no. 01, 2012, pp. 58-67.

Maftuchah, Ainul, Keseimbangan dalam dualitas menurut Sachiko Murata (kajian gender), IAIN Walisongo, 2014.

Mania, Sitti, 'Implementasi Pendidikan Multikultural dalam Pembelajaran', Lentera Pendidikan: Jurnal Ilmu Tarbiyah dan Keguruan, vol. 13, no. 1, 2010, pp. 78-91.

McIntyre, Tom, 'Does the way we teach create behavior disorders in culturally different students?', Education and Treatment of Children, JSTOR, 1996, pp. 354-70.

Miswar, Miswar et al., Akhlak Tasawuf: membangun karakter Islami, Perdana Publishing, 2015.

Mulyono, Galih Puji and Galih Puji Mulyoto, 'Radikalisme agama di Indonesia (ditinjau dari sudut pandang sosiologi kewarganegaraan)', Citizenship Jurnal Pancasila dan Kewarganegaraan, vol. 5, no. 1, 2017, pp. 64-74.

N. Kolis, Kolis, N. (n.d.). Tasawuf Selayang Pandang.

Nugroho, Muhammad Aji, 'Urgensi dan Signifikansi Pendidikan Islam Multikultural Terhadap Kompleksitas Keberagamaan di Indonesia', Attarbiyah: Journal of Islamic Culture and Education, vol. 1, no. 2, 2016, pp. 179-210.

Nurdyansyah, Nurdyansyah and Eni Fariyatul Fahyuni, Inovasi Model Pembelajaran Sesuai Kurikulum 2013, Nizamia Learning Center, 2016.

Prabencana, Doddy, Model Pendidikan Akhlak Melalui Kemitraan Sekolah Dan Rumah: Studi Pengembangan Untuk Meningkatkan Akhlak Mulia Siswa di Sekolah Menengah Pertama Islam Terpadu Al-Azhar Kota Jambi, Universitas Pendidikan Indonesia, 2016.

Pramono, Made, 'Filsafat Seni Taoisme', dalam Jurnal Prasasti, vol. 15, no. 58, 2005, pp. 1-17.

R. Indoensia, 'Indonesia, R. (2003). Undang-undang Republik Indonesia nomor 20 tahun 2003 tentang sistem pendidikan nasional. Jakarta: Pemerintah Republik Indonesia.', Jakarta: Pemerintah Republik Indonesia, 2013.

Rahman, Fadli, 'Pendidikan Multikuttural dalam Perspektif Psikologi Sufistik', Jurnal Tarbiyatuna 
Pendidikan Agama lslam, vol. 1, no. 1, 2011.

Rahmat, Ali, 'Konsep Manusia Perspektif Filosof Muslim', Jurnal Kariman, vol. 4, no. 2, 2016, pp. 41-62.

Rofiq, Ahmad Choirul, 'Ideal Relationship Between Pancasila and Indonesian Muslims', ARISTO, vol. 8, no. 2, Universitas Muhammadiyah Ponorogo, 2020, pp. 274-96.

Rohayati, Enok, 'Pemikiran al-Ghazali tentang Pendidikan Akhlak', Ta'dib: Journal of Islamic Education (Jurnal Pendidikan Islam), vol. 16, no. 01, 2011, pp. 93-112.

S. Siroj, Siroj, S. A. (2006). Tasawuf sebagai kritik sosial: mengedepankan Islam sebagai inspirasi, bukan aspirasi. Mizan Pustaka., 2006.

Siroj, Said Aqil, Tasawuf sebagai kritik sosial: mengedepankan Islam sebagai inspirasi, bukan aspirasi, Mizan Pustaka, 2006.

Somantrie, Hermana, 'Konflik dalam perspektif pendidikan multikultural', Jurnal pendidikan dan kebudayaan, vol. 17 , no. 6, 2011, pp. 660-72.

Suasana, Ene Siti, Negara Pancasila Sebagai Darul Ahdi Wa Syahadah Perspektif Muhammadiyah, Universitas Islam Negeri Smh Banten, 2019.

Subadi, Tjipto, Metode Penelitian Kualitatif, Muhammadiyah University Press, 2006.

Suciartini, Ni Nyoman Ayu, 'Urgensi Pendidikan Toleransi dalam Wajah Pembelajaran sebagai Upaya Meningkatkan Kualitas Pendidikan', Jurnal Penjaminan Mutu, vol. 3, no. 1, 2017, pp. 12-22.

Sutoyo, Sutoyo, 'Tasawuf Hamka dan Rekonstruksi Spiritualitas Manusia Modern', ISLAMICA: Jurnal Studi Keislaman, vol. 10, no. 1, 2015, pp. 108-36.

T. Suryana, 'Suryana, T. (2011). Konsep dan aktualisasi kerukunan antar umat beragama. Jurnal Pendidikan Agama Islam, 9(2), 127-136.', Jurnal Pendidikan Agama Islam, vol. 9, no. 2, 2011, pp. 127 36.

Too, Lillian, Feng shui, Elex Media Komputindo, 1996.

Wijaya, Etistika Yuni, Dwi Agus Sudjimat, and Amat Nyoto, 'Transformasi pendidikan abad 21 sebagai tuntutan pengembangan sumber daya manusia di era global', Prosiding Seminar Nasional Pendidikan Matematika, vol. 1, 2016.

Z. Stapa, 'Stapa, Z. (2001). Insan Kamil: Ciri dan Proses Pembentukan. Jurnal Akidah \& Pemikiran Islam, 2(1), 43-60.', Jurnal Akidah \& Pemikiran Islam, vol. 2, no. 1, 2001, pp. 43-60.

Zohar, Danah and Ian Marshall, SQ-Kecerdasan Spiritual, Mizan Pustaka, 2007. 